\title{
Sustainable Resource Management through Indigenous Knowledge and Practices - A Case of Food Security among the Baiga Tribe in India
}

\author{
Sebestianus Lakra, SJ. ${ }^{1}$
}

\begin{abstract}
India nurtures a tradition of rich civilization traceable from the antiquarian history and its primordial Indian village system. The linguistic relics, artifacts, rudiment tools and implements, skills of reading of the signs and seasons, mythic beliefs, tribal wisdom (sayings and proverbs), concepts and practices are foolproof of the existence of indigenous knowledge and practices. About $75 \%$ of global population is home to indigenous peoples and culture capable of deriving sustainable resource management. The knowledge of the local people tested over long period, adapted to local environment, then being passed down from one generation to another still has the carrying capacity of sustainable food security, health care, and ecological protection. The Baiga known for his cultural heritage, whose indigenous knowledge and practices is in transition but has relevance for sustainable resource management in resource depletion. The present work is an ethnographic study on the subject, in which the researcher used participant observation for data collection on food security through indigenous methods of farming. Open ended ethnographic interviews were conducted to the key informants.
\end{abstract}

Keywords: Indigenous knowledge and practices, sustainable resource management, food security, Ethnographic, participant observation, organic farming, food security, Nutri cereals, Baiga Chak, PVTGs, Dähi

\section{Introduction}

India has been nurturing a tradition of very rich civilization since time immemorial. This civilization has its root in the primordial Indian village system which rose from stone culture to agriculture and then as ruling races of antiquarian confederation. The rudiment tools and implements, the reading of the signs of the seasons, the mythic belief systems which culminated into ancient scriptures, teachings of the sages, innumerable sayings and proverbial wisdoms all contain profound store house of ideas and knowledge, concepts and practices. The linguistic relics, artifacts, rudiment tools and implements, mythic beliefs, concepts and practices are foolproof of the existence of indigenous knowledge and practices. The knowledge of the local people tested over long period, adapted to local environment, then being passed down from one generation to another contributed to $75 \%$ of global population as key to development wherever indigenous peoples and cultures existed or continue to exist remotely or on substratum. Still this can show us as alternatives to sustainable development.

Though the concepts and paradoxes behind Indo-Dravidians, Indo-Germans, TuranoDravidians, or Indo-Aryans have gone down in the memory lane and have become almost obsolete but India still holds these paradoxes in the forms of cultural diversity, the caste systems, and the tribal groups. As they may be traced from the art and artifacts 
and from linguistic relics, this indicates to a hypothesis that in some point of time the original stock of Indian race underwent racial infusion. The researches show that the matriarchal race of Indian origin in its zenith of civilization spread and planted its matriarchal system of colonies, governance throughout Indian land and sent its colonies far to other countries not only to East-Asian but also to South-Asian countries, AsiaMinor, and Western Europe in the Neolithic age. We trace the racial infusions between the tribes of the Indian matriarchal family systems with the racial groups of those countries viz. the mountaineers of the east with the Mons (sons of the tree), the Ural Altic Finns, the German Basques, Turanians, Aryans and Mongolians, not improbable. The new races other than matriarchal tribes in India, as resultant from such infusion came back to India for political end, and we witness the present cultural systems in India. The present diversified cultural groups, the caste systems, the political organization that exist in India could be seen as resultant racial and cultural infusions. Thus, we have Dravidian, Kolerian, Aryan or Brahminic, Mongolian Muslim cultural substratum. The modern research is showing that these are traceable in the age of digital communication; and thus we can see the extent of the spread and impact, influence in the racial, cultural, and political development not only in India but also the countries the matriarchal family systems sent its colonies and cultures. We can glean the indigenous knowledge and practices that develops into the matriarchal tribes in India by transferring these knowledge systems from one generation to another. From these systems of sustainable resource management we intend to draw benefice and relevance in the present day development paradigm. Curiously, the Indian primordial village system of civilization has much to shed light, and more particularly the Baiga tribe. Hence, this study is an attempt to gauge into sustainable perspectives of resource management through indigenous knowledge and practices of the Baiga tribe in Dindori District of India in relation to its systems of food security through its traditional system of Bewar cultivation, the age old shifting agricultural practice.

\section{Baiga Tribe of Dindori District in Madhya Pradesh (India)}

The Baiga tribe is one among the seven PVTGs (Particularly Vulnerable Tribal Groups) in Madhya Pradesh and Chhatisgarh. The other PVTGs are Abujh Madiyas, Pahari Korwas, Birhors, Sahariyas, Kamars, and Bharias. The Baiga tribe inhabits in Central India in the heart of Mikal range in the eastern Satpuda hills: the catchment of the Narmada and its tributaries with fertile valleys and thick forests, on the table land in close proximity with nature. In other parts of India, the tribe exists in Baihar (subdivision of Mandla), North-east hilly regions of Kabirdham District, Northern subdivisions of Bislasprur (Pendra, Gaurela blocks), Katghora subdivision (dense Sal forest area of Lormi), Supkhar forest area of Balaghat District, in the districts of Annupur, Shadol, Reva, Umaria and Jabalpur. In Surguja of Chhatisgarh, in Maharashtra, they exist sparsely. However, Census records (1981 and 1991) show Baiga population in Palamu (Jharkhand), West Bengal (2.3\%) Bihar (1.2\%), Orissa (0.5\%) and Mharashtra $(0.35 \%)$.

Not before long, about four generations ago, the Baiga had nomadic life - migrating from one jungle to another in search of hunting and gathering food. But now he lives in villages as settled life adopting present day agricultural practices. Some of them are at 
par with the other castes of the plain area. The Baiga is known across the country for its cultural heritage and life styles. Their main concentration is Dindori district of Madhya Pradesh, India. According to the Census (2011) total Baiga population in the district of Dindori was 42,109 of which about, $99.04 \%$ of the Baiga population lived in the rural areas. Currently, the percentage of the Baiga villages is marked $23.20 \%$ of the total inhabited villages in the district. Of the total 74 Baiga villages with $2771 \mathrm{HHs}$ (households) reveal no villages have $100 \%$ with Baiga HHs or population. The highest concentrated Baiga household villages are Dhaba with $83 \%$ and Jhilang with $80 \% \mathrm{HHs}$ and the rest of them less than 75\% HHs. In Dhaba $90 \% \mathrm{HHs}$ are of the Baiga, 9\% $\mathrm{HH}$ are of the tribe belonging to the Gond and 1\% HHs is of the OBC (Other Backward Caste). In Jhilang 83\% HHs belong to the Baiga and 17\% $\mathrm{HH}$ belong to the Gond. In other Baiga villages (having less than $80 \% \mathrm{HHs}$ ) the Baiga concentration or the Baiga population may be discernible.

The present study is conducted in the District of Dindori in the state of Madhya Pradesh. However, the location of the study, in general is the Baiga Chak (the Bawan gram (52 villages)). These villages predominantly are under the blocks of Karanjia, Bajag and Samnapur of Dindori district.

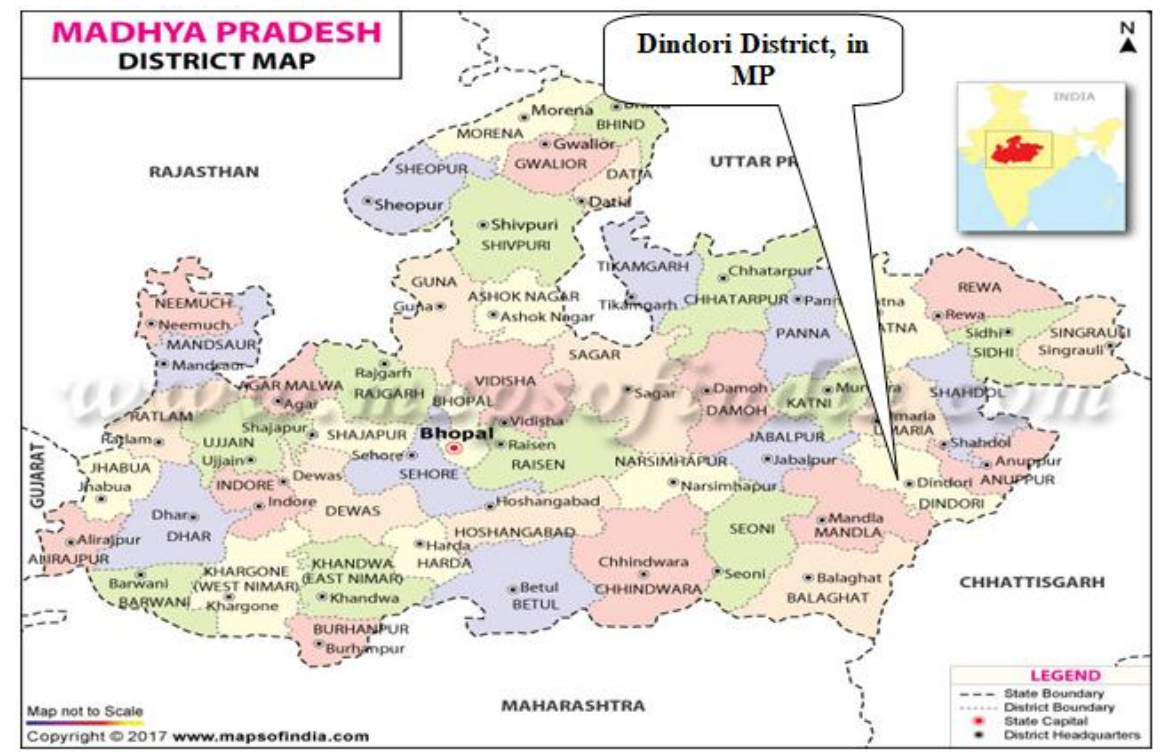

Map No.1: Map of Madhya Pradesh-Showing Dindori District

\section{Statement of the Problem}

Indigenous Knowledge and Practices is a key to sustainable food security.

\section{Relationship to Existing Theories or Perspectives in the Field}

The literature review on the subject of indigenous knowledge and practices indicate of an increasing interest worldwide. However, resource management through 
indigenous knowledge and practices is a growing subject in sustainable development. The present development paradigm has blended indigenous knowledge and practices for sustainable growth model. The conscious academicians, development catalysts, environmentalists, urge to go to the root; the native knowledge, for it is the root of all knowledge- unique to a culture or society. 'Best practices using indigenous knowledge' (Jun, 2002) illustrates 22 best practices of indigenous knowledge in the sustainable development for poverty alleviation and income generation.

Indigenous knowledge, forest management and forest policy in South Asia (Seeland, 2003) reflecting on the Indian context, and more particularly of Orrisa, it highlights the relevance of indigenous knowledge of various South Asian tribal and rural communities in the sustainable management of forests and local resources. It reinforces the relevance of indigenous knowledge as a development tool, and emphasize of both collective initiatives at the grassroots level and securing the locally accepted patterns of livelihood for the tribal and village communities. The Resource Management through Indigenous Knowledge by D.K. Behera, (Behera, 2000). reasserts relevance for sustainable development in terms of being a catalyst rather remaining as 'past story'. It shows how indigenous knowledge and skills continue to exist by transfer from one generation to the other which 'adapts and adds to this body of knowledge in a constant adjustment to changing circumstances and environmental conditions'. It has shown that the best approach to resource management envisage 'the combination of traditional and new methods in development interventions' for "ignoring the indigenous knowledge system in design and implementation of development projects is an impediment for sustainable development" (Brower, 2000). Indigenous Knowledge, Natural Resources: Konda Reddi Experiences documents the rich indigenous knowledge, local practices of natural resource management and common property resources among the Konda Reddi of Andhra Pradesh, India. The Konda Reddi, the Primitive Tribal Groups (PTGs) inhabiting the North Eastern Ghat region of Andhra Pradesh from centuries and primarily subsisting on swidden (shifting) agriculture like the Baiga tribe in Central India. (Basa, 2008).

\section{Objectives of the Study}

The application of indigenous knowledge and practices in sustainable development is inevitable. Hence the following are the objectives of the present research study:

- Examine the traditional food production or livelihood systems of the Baiga tribe.

- Explore the inherent ecological conservation practices of the Baiga tribe.

- Study the nutri-elements in the food intake of the Baiga tribe.

\section{Methodology}

The "The Resource Management through Indigenous Knowledge and Practices of the Baiga Tribe in the District of Dindori, Madhya Pradesh" is an ethnographic study. Hence, it is a Baiga ethnography. The study was conducted in Dhaba and Jhilang . Dhurkutta (forest village of Baiga Chak) also covered while other forest villages under 
Baiga Chak, like Chanda, Tantar, Kandawani, Ajgar were covered under transect walk to take a stock of the situation of the Baiga tribes in general. To understand the location the researcher also made many rounds of area visits of the district. All these visits and inquiries helped the researcher in taking stock of the areas of the district, the forests, natural resources, and the people in general and Baiga tribe in particular. After the preliminary visit of the location, information pertaining to the subject was collected through the literature review. Then the ethnographic study followed. Participant observation technique was adopted. Several open ended ethnographic interviews, discussions were conducted with the key informants and also of the persons who are experts and knowledgeable in their cultural areas. A pool of information was generated. From this pool of information (a large sample of utterances as expressed in the language used by informants) several samples (in the form of key concepts, words, phrase, rituals, symbolisms, artifact, etc. were taken for further analysis. The last major task of ethnographic study was making ethnographic description or writing descriptive ethnography.

The ethnographic research study employs non-probability sampling. Hence, "population, in ethnographic research, is not always made up of human beings, but they constitute communities, organizations, programs, animals, places or things, time periods, documents, words, phrases, sentences or paragraphs in interview texts and transcripts, specific activities or bits of behavior or almost any unit whatsoever. These forms of populations have large coverage; and they may be embedded within other groups, organizations, activities or settings, or scattered over a number of sites" (Schensul \& LeCompte, 2013:280). In collection of cultural data, few key informants rather than on a representative sample were taken. They were selected on the basis of their cultural competence. They were from the villages of Dhaba, Chhote Dhaba, Baigantola (Gaura), Jhilang, and Dhurkutta. The informants were sometimes cross checked, for the samples picked up from the pool of information to verify the sense, meaning or symbol as commonly understood. At other times individuals were taken as experts in the area of knowledge. On the basis of cultural competency other Baiga men and women were taken as sample in the ethnographic studies. Similarly, the artifacts ${ }^{1}$, concepts, symbols, rituals, etc. used in cultural practices are samples in this study to know the subject in investigation. This study is exploratory and descriptive in nature. It has adopted tools and techniques of qualitative data gathering, analysis and cultural description.

Inquiries were made and ethnographic questions were asked directly in the cultural scene' while the Baiga worked in his field, while in cultural activities like; while the Dewars extracted herbal medicine and administered them to cure sicknesses; while the Baiga distilled liquor in the river side; while he worked bamboo craftsmanship; while he worked on tiles, etc. On other occasions, the researcher observed the herbal seeds, roots, stems, leaves being sold in the market for price, attended the Gram sabha meeting in Jhilang, the Baiga meeting held at Chanda for the safeguard of habitat right, visited Chubi khadan, the bauxite mines at Daldali, discussed, and listened the agony of the Baiga

1 Artifacts are portable objects with physical evidence that they have been manufactured, modified or used by humans. There are many millions of recorded artifacts, including spear and arrow points, pottery and jewelry. Projectile points, potsherds, wood, plant fibers, bone and shell (Nation, 2009). 
people who were displaced due to the mining operations. The ethnographer recorded the information in the field notes, took visuals and video clips. All these helped the researcher in bridging between observation and analysis of the social situation of the Baiga tribe in relation to sustainable resource management. The initial recording and analysis helped the researcher to decide for various samples to be taken for further and deeper analysis of the subject in investigation, narrowing down to make selective descriptive observation.

\section{Traditional Livelihood Systems of the Baiga Tribe}

The Baiga believed that they were 'established in the practice of Bewar by Bhagwan himself...' (Elwin, 1939:106) and thus the Baiga claims it to be an age old cultivation system. This system was allowed in the Baiga Chake (Elvin, 1939:116); while in the other areas of the district it was restricted by policy in British India. The Bewar (shifting cultivation) may be learnt as described below-

'....with no other instrument of agriculture but their axe and a small sickle, it is astonishing to see the extent of clearing one village of Bygas makes on the sides of the hills of which their village is located. Until lately, it was their habit to select the spots for their dhyas with an utter disregard for all the rules of forest conservancy. Where the trees are largest and most numerous there will be the Byga resort, and in the cold weather months will cut down sufficient wood to cover pretty closely the whole of the area he means to bring under cultivation. In May and June, just before the setting of the rains, this wood and the brush wood in which it has fallen, is set fire to; and almost before the fire is out, the Byga may be seen taking up the ashes and spreading them over the whole surface of their field; this is done either with a bundle of thorns or with a long bamboos, until there is a superstraum of about an inch of ashes spread over the ground. In these ashes they sow kodon, koodke, and occasionally a poor specimen of rice, called here 'bygana' (Elwin, 2007:108).

As indicated the Bewar was weaned by policy the Baiga was forced to live a life of settled agriculture. Only in the Baiga Chak (as an area of 23,920 acres of Block 54 curved out in 1890) Bewar cultivation was permitted. We trace since then the Baiga has his settled life, and were induced for plough agriculture. Consequently, the bewar fields in their possession remain with proprietary right. However, their land remains on periphery on the hill slopes. In these hill slopes they still cultivate with bewar methods wherever, the plough cannot reach; and the rest under plough agriculture. Under these circumstances the Baiga tribe has their livelihood systems through indigenous knowledge and practices. It is observed that cultivation practices, is 'Organic by Default'. Crop rotation viz. maize-mustard crop rotation is commonly practiced in the homestead or backyard field, while crop rotation kodo-kutki-Ramtila-kodo-kutki-fallow practice is still in vogue in hill slopes. The crop rotation is followed. The normal practice of crop rotation is- KodoKutki and ramtilla. According to the Baiga agricultural practices: the land is to be kept fallow for a year (after three subsequent cultivation in crop rotation), and then again crop rotation can be followed. The fallow period revitalizes the soil naturally.

2 Originally eight villages: Daharkata, Silpuri, Tantar, Dhaba, Ajgar, Jhiling, Lamota and Rajni Sarai 


\section{(A) Kutki (Millets)}

There are different varieties of Kutki which are grown by the Baiga even in the present day cultivation practices. These are Bade kutki, Salhar kutki, kat-ki, sitabi kutki3or kadiya (black) kutki, Naang Dawan kutki and Bhadeli kutki. Bade kutki, Salhar kutki, kut-ki are the crops of donger kheti (bewar cultivation) while the other millets are sown under plough cultivation. The history and discovery of the millets and the practices of millet growing may be learnt from the ancient indigenous cultivation practices (Hewitt, 1894: 47-48; 59$60)$.

The name of gundli is not known by the Baiga. However, they know it by bhadeli kutki. It takes the shortest period among the kutkies (millets). Formerly, cultivated as bewar cultivation. It is the earliest yielding crop; harvested in the month of Bhado (the second half of the month of August) and hence, its name Bhadeli (crop harvested in the month of Bhado). It is the gundli or bhadeli kutki which was among the first grown or discovered by the women of the ancient matriarchal society of the forest tribes of India, of which the Baiga belongs. Chhoti kutki): Sitahi kutki or kadiya (black) kutki, Naang Dawan kutki and Bhadeli kutki (gundli) are considered Chboti kutki (Early variety millets). The chboti kutki is sown in the month of August. Bade kutki (late yielding variety millets) are Salhar kutki, Kang, Kat-ki and Sikiya and are sown broadcast under Bewar cultivation, before the onset of the monsoon. The field is prepared by burning the cut bushes (bush plants in the field are cut and dried in the months of Baisakh and Jeth (April- May). Spread the ashes in the field as far as possible. Sow seeds broadcast. When the plants grow, as per the need, weeding is conducted. The field is fenced with cut bush to protect from the animals such as cows, ox and goats. Earlier, fencing was meant for preventing wild animals. Since the restriction under policy bewar cultivation is being shifted to plough cultivation. Hence, bade kutki is now under plough cultivation. The Baiga sow bade kutki, wherever, plough can reach in the upland field which is intended for bade kutki cultivation. The soil preparation and weeding are similar to as in the sowing of Chboti kutki. Fencing is used for the prevention from easy effecting by cattle into the field. It is harvested in the month of Magh (January). Kodo (Varagu)- is said to be the crop of the Kissan, the Gond and the present rice cultivation system is of the Gond. Kodo and Arbar (Cajanus indicus) go well as mixed cropping. In the month of July, it is sown and harvested in the month of Pus (December), and the Arhar in January. It is observed that the Kodo or other cereals sown under plough cultivation, is of poor quality compared to Bewar cultivation.

(B) Bewar Kheti (Shifting cultivation) - Tillage Practices, Soil Fertility, Cropping Patterns, Farm Implements and Pest Control in Bewar Cultivation

By and large the portions of occupied land or field Baiga are on hill slopes on which they still continue to cultivate not in strict sense of Bewar cultivation. As observed in the area and learnt from the informant the method of Bewar cultivation still in practice on the hill slopes; and here they stay in their watch hut whole day. These fields give a vivid picture of the Bewar cultivation in the season. A bewar cultivated field may be the size of 5 acres of land and in that they sow Kodo (Varagu), Kutki (Bade kutki), Madia, Salhar kutki, Rahar/ Arbar (Cajanus indicus), Barbatti, Kheera, Badra (kurthi), Sikiya. It was observed

3 Sitabi in Baiga dialect means seet (dew drops or night moisture). It is sown after the rainy season and its seed germinates, grows and sustains in the moisture of dew drops. Hence, it's name sitabi after seet. 
total eight crops were sown under mixed cropping pattern. It is said to be many more type of crops. They cut no more Bewar today, but follow the Bewar cultivation practices. In the summer they cut the bushes and shrubs of the field or bring some cut bushes from outside the field and spread over the field. When it dries, they burn them. In the summer the cattle pass through the field and naturally dust them off. After the Bidri ceremony (ritual for sowing seed), and before the rain, they sow the seed broadcast. These seeds are kutki (bade kutki), madiya/kodai (Elenisine indica) (raggi) Salhar kutki and Sikiya. When the rainy cloud appears, other seeds like Arhar, badra, barbatti, Kheera are dibbled with khanta (a pointed iron tool for dibbling Rahar/ Arhar (Cajanus indicus) and digging up of the jungle kand-muls.).For sowing no much labour is required. Hence they do by themselves; while dibbling the Arbar and other seeds, they employ labours spending about Rs. 500 to 600. Bewar cultivation requires two weeding, first, while the plants are infant and second when they have grown the height of knee. If the crop is bumper, it will cost about Rs. 1000 to 1200 in harvesting. As the crop is ready, they crop them with sickle or hands. Then there is second and third cropping likewise.

They do not cut the stem nor damage them with the root. The stem and twigs remain for next year cropping. Sparing the stem thus, they are able to harvest till three successive years from the old plants particularly of Arhar (Cajanus indicus). It is the main crop in the Bewar. It has its principle of taking successive crops for three years. Cattle (cows, buffaloes and goats may eat its leave and small twigs, but finally will remain the stem. Eventually, in this process, the soil will have natural dust. When it receives the next rain, it brings forth afresh and strong twigs as a result of natural pruning. The same process is repeated for the third successive year. However, the crop may lessening every yield.

On knowledge transfer of this Bewar cultivation the informant told that the whole village practiced the Bewar cultivation. Together with the cultivator, the researcher roughly calculated the cost and income of the Bewar cultivation. The farmer expects Rahar/ Arhar (Cajanus indicus) yield three to four quintals per the size of bewar cultivation. The selling price per kg. Rahar/ Arbar (Cajanus indicus) seed is about Rs. 50. In the market Rahar/ Arhar (Cajanus indicus) pulse as final product is about Rs. 90 to 100 per $\mathrm{kg}$. At least one quintal of the pulse will be for home consumption and the rest to sold in the market with the average rate of Rs. 50 per kg. Thus, Rs. 10000 to 15000 income is collected alone from Rahar/ Arhar (Cajanus indicus), while the other crops are not calculated. For, other crops, they harvest and consume as per the need.

The other supplementary bewar crops as Baria Baiga says, are Keda and Sakla Kand. Sakla Kand was cultivated in the bewar field with Kuduari (a small spade). The plot for sakla kand is about one hariya (approximately 10 feet width and 25 feet length). The Yeild of sakla kand from this size of plot was about 4-5 sack (about two quintals). With the harvest of other crops in the month of Kartic (October) Sakla kand is extracted, boiled and eaten. The other supplementary crop in the Bewar cultivation, was planten (banana). Few households have plantens in their kundbari. Kandavadi/wani, Kandagaon, kanda dongar, Kede dongar, kedegaon were the names of the villages, where Sakla kand or Kand in general and keda (banana) were produced and thus the village names after the production of such produce. Now kede (banana) is almost vanished.

The Bewar cultivation is 'organic by default'. It is told that Bewar requires two weeding. After the weeding, the grass are left and heaped under the crop plants for getting them 
decomposed and thus natural recharge of nutrients for the plants. It is observed that the crop plants healthy strong and with a good height. It was observed that while the plough agriculture in the area was declared as failure, the Bewar cultivation of the Baiga was unaffected or less affected. In the Bewar cultivation -bade kutki, Kang, katki and sikiya are sown without plough partially or whole field. With seeing the growth and size of the plants $^{4}$, and the simple analysis of the crop productivity of the last year, it is easier to conclude, that the cultivation through Bewar method, even in the less rain or sporadic rain, the crops can be taken easily, organically, and with less cost in the labour intensive agriculture.

(C) Bewar Rice Cultivation:

In the month of Jeth (May), where ever there was possibility of growing rice or places may likely to be damp in the rainy season, the leave branches were cut heaped and fired when it was dried. From the bark of the tree they made sandals or sleeper and wearing them, held a long stick and pushed back the fire bush- heaped with the stick further and further, back till it reached to the end point. This pushing the fire back from front with stick wearing the bark sleeper on feet is known as Dāhi Dhonkai. Mohan Samardaiyha of Jeelang and Budhsing Murkundiya of Baiga Tola (Gaura) have affirmed the system that their forefathers had practiced of such agriculture in growing of paddy, the rice much acclaimed of the origin of agriculture by the ancient matriarchal foreparents of the forest tribes. On this field thus ash spread, the paddy was sown without plough. With Kuduri the field was scratched or dug and there seeds of Sathia, Ratwa and Niwadi were sown. Sathia paddy has black rice, Ratwa has red and Niwadi has plain white rice. The sathia rice has religious significance among the other Kolerian tribes. Rice beer tablets were made from the powder of sathia rice; and rice beer among the Kolerian tribes has similar significance as of liquor among the Baiga. Moreover, the rice in Kerala of similar kind is staple food.

We have seen madiya/kodai (Elewisine indica), kutki, kangni, jowar (Halcus sorghum), sanwan, salhar, rice are cultivated in the Bewar method partially. The nutrition value (per 100 gram) of these cereals as indigenously grown by the aborigine Baigas may be seen in the following table; and it is for our discernment how scientific were the knowledge and practices of the Baiga tribe in matters of cultivating cereals of nutrition values; and thus in their intake of food calories is discernible.

The table below (table No.1) shows the nutritive values in the cereals the Baiga grows for his food. These cereal foods were considered as 'poor man's food', tribal food, and almost neglected. Now the same are considered nutrient food compared to Rice and wheat. To-day it is marketed as Nutri Cereals. These are apparently recommended in the national Food Security Act, 20135(2013:15).

\footnotetext{
${ }^{4}$ Baria counted one of the Bade Kutki in his Donger khet which has brought forth 30 healthy twigs and shoots from one seed plant. The height of this plant is higher than the cultivator.

${ }^{5}$ Eligible households shall be entitled to food grains under section 3 at the subsidized price not exceeding rupees 3 per $\mathrm{kg}$ for rice, rupees 2 per $\mathrm{kg}$ for wheat and rupee 1 per $\mathrm{kg}$ for coarse grains for a period of three years from the date of commencement of this Act, 2013.
} 
Table No.1: Nutrition Values of the Cereals Produced by Baiga (all- per 100 gms)

\begin{tabular}{|c|c|c|c|c|c|c|c|c|c|}
\hline Cereals & 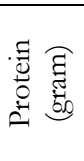 & 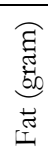 & 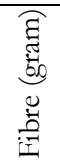 & 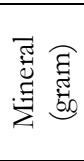 & 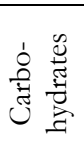 & 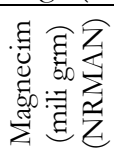 & 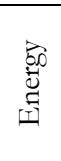 & 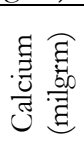 & 劳 \\
\hline madiya & 7.3 & 1.3 & 3.6 & 2.7 & 72.0 & 137 & 328 & 344 & 3.9 \\
\hline Kutki* & 7.7 & 4.7 & 7.6 & 1.5 & 67.0 & 133 & 341 & 17 & 9.3 \\
\hline Salharkutki & 10.6 & 4.8 & 1.3 & 2.3 & - & 137 & - & 38 & 16.9 \\
\hline Kangni** & 12.3 & 4.3 & 8.0 & 3.3 & 60.9 & 81 & 336 & 31 & 2.8 \\
\hline Jowar & 10.4 & 1.9 & 1.6 & 1.6 & 72.6 & 171 & 349 & 25 & 4.1 \\
\hline Sanwan & 6.2 & 2.2 & 9.8 & 4.4 & 65.5 & 82 & 307 & 20 & $\begin{array}{l}5.0 \\
15.2\end{array}$ \\
\hline salbar & 10.6 & $\frac{2.2}{4.8}$ & 1.3 & $\frac{7.4}{2.3}$ & - & $\frac{02}{137}$ & - & 38 & 15.2 \\
\hline $\begin{array}{l}\text { Kodo } \\
\text { (varagu) }\end{array}$ & 8.3 & 1.4 & 9.0 & 2.6 & 65.9 & 147 & 309 & 27 & 0.5 \\
\hline Rice *** & 6.8 & 0.5 & 0.2 & 0.6 & 78.2 & 64 & 345 & 10 & 3.1 \\
\hline Rice rhp & 7.5 & 1.0 & 0.6 & 0.9 & 76.7 & - & 346 & 10 & 3.2 \\
\hline Wheat & 11.8 & 1.5 & 1.2 & 1.5 & 71.2 & 90 & 346 & 41 & 5.3 \\
\hline
\end{tabular}

*Samai, ** (Italian millet) *** Rice (raw, milled), Rice rhp (raw hand pounded)

Source 1: National Institute of Nutrition (Indian Council of Medical Research (ICMR): Revised ed. 1989; reprinted 2012, Table-1 Proximate Principles-Common Foods, p. 47; Italics: sourced from NIRMAN Vaikalpik. Vikas Evam Sabbhagi Shodh Sansthan, Bichbiya, Jila Mandla (M.P)

(D) Bari Kheti (Homestead Gardening) a Replication of Bewar Cultivation

Formerly, the maize seeds were dibbled in the Bewar field. The concept of Bari did not exist and has come with the plough agriculture. With the advent of Bari, the maize cultivation formerly (Bewar cultivation) was brought in the Bari with or without plough. Without plough the maize and other seeds were dibbled. But gradually the Bewar cultivation was replicated in the Bari cultivation. Now Loda, Junwar, Rawans, Badra, Kang, kat-ki, barbatti, Kheera, dengra (bodela), Chench bhaji, Purpuri bhaji (Amaranthus bybridus), Khutni Bhaji, etc. are sown broadcast under plough cultivation. With loda (maize) goes Rahar/ Arhar (Cajanus indicus) as mix cropping. The field preparation of the Bari is as the local practice among the Gonds. Soon after the harvest of the Bari crops of the rainy season, the field is cleared from corn sticks, ploughed and Bakhar-Dantri (fork plough) is run for further clearing the grasses and waste residues of the previous crops. Then they saw mustard seeds. The harvest of the Bari crops yield substantially and they are organic to great extent.

The Bari is usually fenced with strong wood erected straight along the borders. Usually they are khunta (strong and dried wood log) fencing. This is quite durable; and it may last about 15 years or more. The second type of fencing the Bari is planting hedges or custard oil plant along the borders. This is lifelong fencing. Only occasional maintenance and pruning is required. The third type of fencing is temporary fencing. Thus, the Bari holds a sample or replication of crop fields as of Bewar cultivation to some extent and form.

The table below (Table No. 2) shows the nutritional value of the pulses and legumes produced by the Baiga in the method of semi Bewar cultivation. This indicates that the Baiga is rich in his food intake in terms of per calorie. These food grains are rich in nutrition. 
Table No. 2: Nutrition Values of the Pulses and Legumes Produced by Baiga (all values-per 100 gms)

\begin{tabular}{|c|c|c|c|c|c|c|c|c|}
\hline Cereals & 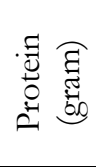 & 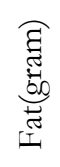 & 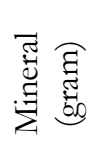 & 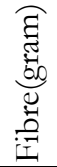 & 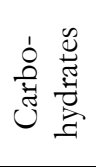 & 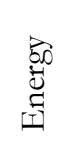 & 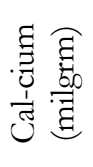 & 总 \\
\hline Cowpea & 24.1 & 1.0 & 3.2 & 3.8 & 54.5 & 323 & 77 & 2.7 \\
\hline Field Bean & 24.9 & 0.8 & 3.2 & 1.4 & 60.1 & 347 & 60 & 9.3 \\
\hline Black gram dal & 24.4 & 1.4 & 3.2 & 0.9 & 59.6 & 347 & 154 & 3.8 \\
\hline Khesari dal & 28.2 & 0.6 & 2.3 & 2.3 & 56.6 & 345 & 90 & 6.3 \\
\hline Lentil & 25.1 & 0.7 & 2.1 & 0.7 & 59.0 & 343 & 69 & 7.58 \\
\hline Rajma & 22.9 & 1.3 & 2.3 & 4.8 & 60.6 & 346 & 260 & 5.1 \\
\hline Red gram dal & 22.3 & 1.7 & 3.5 & 1.5 & 57.6 & 335 & 73 & 2.7 \\
\hline
\end{tabular}

Source 1: National Institute of Nutrition (Indian Council of Medical Research (ICMR): Revised ed. 1989; reprinted 2012, Table-1 Proximate Principles-Common Foods, p. 47;

\section{Main Findings}

Tillage, harvest and storage techniques are simple, traditional and low cost compared to labour intensive agriculture. In the bewar cultivation there is no pest and hence no chemical pest control system. The base of their belief that the bidri ritualized seed on sowing is not prone to be infected by pests. However, these days, the seeds before sowing, Chandan or Salhe (Boswelia serrata)) leaves (green) are rubbed together. The agricultural tools sickle, dibble, Bakhar, Dantri are all indigenously produced and hence low cost agricultural tools and implements. The storing techniques of the grains are also indigenously made as Khudsa with bamboo craft and kothi with mud cell. The food preparation (from husking to cooking food) is indigenous. The cereals, pulses and legumes are chemical free products with highly nutritional values. Cropping pattern is simple and practical. They follow kodo-kutki- Ramtila-kodo-kutki-fallow. The fencing systems are sustainable and eco-conservative.

\section{Conclusions and Implications}

The Bewar cultivation method is 'organic by default' and about $60 \%$ of Indian agriculture is said to be organic by default. Hence, India has large area and scope in the sustainable food production. These agricultural practice 'organic by default' is dry land agriculture and occupied by the tribal and rural communities. These communities have inherent tradition of indigenous knowledge and practices on sustainable agricultural practices. India can produce the required volume of food with highly nutrition values and secure its sustainable food security. The food production system through indigenous knowledge and practices as seen in the Bewar method of cultivation, it is successful and effective method for climate change mitigation for even in the less rain or sporadic rain, the crops can be taken easily, organically, and with less cost in the labour intensive agriculture. The cereals, pulses and legumes produced by the Baiga in the method of semi Bewar cultivation have rich nutrition values. Hence, rich in his food intake in terms of per calorie is discernible. These food grains as rich in nutrition and rightly 
recommended once for National food security, could be promoted in the Mid Day meal supplied for school going children under RTE (Right to Education) as Nutri food or cereals in the country.

\section{References}

Basa, K. K. (2008). Indigenous Knowledge, Natural Resources: Konda Reddi Experiences. (B. K.K., Ed.) Pratibha Prakashan.

Behera, D. K. (Ed.). (2000). Resource Management through Indigenous Knowledge System [Special Issue]. Journal of Social Sciences, (5)

Brower, J. (2000). Practices are not Without Concepts (Reflections of the Use of Indigenous Knowledge in Artisnal and Agricultural Projects in India), in DK Behera (ed.) Resource Management through Indigenous Knowledge System [Special Issue]. Journal of Social Sciences, (5)

Elvin, Verier. (1939). The Baiga. London: John Murray, Albemarie Street, W.

Elvin, Verier. (2007). The Baiga. New Delhi: Gyan Publishing House (First published in London John Murray, Albemarie Street, W.1939).

Hewitt, J.F. (1894). The Ruling races of Prehistoric Times in India, South-Western Asia and Southern Europe. MDCCXCIV: Westminister Archibald Constable and Company, Publishers to the India Office, 14 Parliamnt Street, S.W. (Forgotten Books: www.forgotten books.com; Copyright @2016 FB \&c Ltd.)

Jun, B. K. (2002). Best Practices Ussing Indigenous Knowledge. Paris: Nufic the Hague, The Netherlands and UNESCO/Most.

Schensul, J. J. and LeCompte,M.D. (2013). Specialized Ethnographic Methods (second ed., Vol. 3). (M. D. Jean J. Schensul, Ed.) Lanham, New york, Torronto,Plymouth, UK: Altamira Press: Adivision of Rowman \& Littlefeild Publishers, Inc.

Schmithusen, F. a. (2000). Man in the Forest Local Knowledge and Sustainable Management of Forests and Natural Resources in Tribal Communities in India (Vol. Man and forest). New Delhi: D.K.Print world. 